\title{
Basson's private ECG tutoring sets pulses racing
}

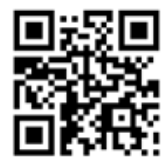

Professionally disgraced apartheid-era architect of chemical and biological 'dirty tricks' weaponry Dr Wouter Basson continued to tutor Stellenbosch University medical students at a private medical hospital for 11 months after being convicted of unethical conduct.

The maverick clinician's involvement with young medical minds has drawn fire from top ethicists and the official campus student medical body. The latest twist in the tortuous 14-yearplus drama surrounding the unrepentant cardiologist, found guilty of unethical conduct in December 2013 by a Medical and Dental Professionals Board (MDPB) conduct tribunal, prompted belated but vigorous debate on the Stellenbosch medical campus. His second appeal to the Supreme Court to have the MDPB tribunal recuse itself on grounds of its being 'biased' by having failed to disassociate itself from a South African Medical Association (SAMA) statement supporting a petition calling for the 'strongest possible censure' of him is due to be heard on 9 February. Basson's lawyers walked out of what would have been the start of his sentencing in December 2014, claiming that tribunal members Profs Jannie Hugo and Eddie Mhlanga were members of SAMA and therefore inherently biased. Basson's team returned in April last year, bearing a High Court-approved order that the tribunal hear their application for recusal. The tribunal complied, but turned it down flat, chairperson Hugo saying that he and his colleague were inactive in SAMA management, with their association confined to academic and professional work. Hugo assured Basson that he and Mhlanga were 'acutely aware of our duties in this matter,' and pledged to ensure that he continued to experience a fair trial. Undeterred, Basson and his lawyers then applied to the High Court to overrule the MDPB response.

\section{Ethicists speak out}

Meanwhile Prof. Keymanthri Moodley, head of the Centre for Medical Ethics and Law at Stellenbosch University, criticised both students and her own Faculty of Medicine and Health Sciences for allowing Basson's continued tutelage at the Durbanville MediClinic for 11 months after he was found guilty. His tutorials to 4th-year undergraduates around interpreting electrocardiograms were part of a public-private initiative to increase early exposure of students to private sector practice. Upon hearing of this, the Stellenbosch medical faculty (in an unprecedented step) revoked Basson's teaching rights on 4 November 2014, a full 11 months after the MDPB guilty finding - his tutelage reportedly having rendered several students 'acutely uncomfortable. Prof. Ames Dhai, Director of the Steve Biko Centre for Bioethics at the University of the Witwatersrand, asked what responsible parent would want their child taught by a man dubbed 'Dr Death'. She said it was 'shocking that in this day and age

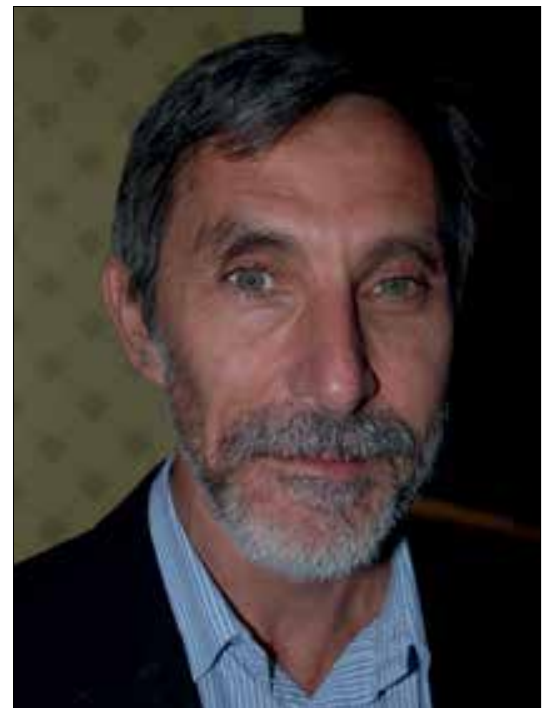

Prof. Jannie Hugo.

and with our [SA's] history of human rights abuse, Stellenbosch would not have taken a decision immediately in terms of his guilty finding. Going through all those committees is not a reasonable sort of explanation for an 11-month-long delay.'

Tygerberg Student Council chairperson Nick Wayne said that his council stood by its call that no student should be taught by Basson. While no one was forced to take his class, there were students who did not want to be taught by him and believed he should not be practising at all, let alone 
teaching. 'Teachers instil certain qualities of themselves in their students, and his lack of remorse and involvement in apartheid warfare makes students very uncomfortable. They would rather have other tutors', he added. Prof. Marietjie de Villiers, Deputy Dean of Education in the Faculty of Medicine and Health Sciences at Stellenbosch University, described the anomaly as 'a technical difficulty'. 'There's a difference between being appointed and being on the teaching staff, and being accredited as a clinical supervisor,' she explained, adding that Basson had never taught on campus. While Medi-Clinic had been accredited as a 'group', the individuals giving tutorials also had to be named, she confirmed. 'People use the word "taught" loosely', she said. Explaining the 11-month delay in revoking Basson's teaching rights after he was found guilty, she said the process began after the 2013/14 festive season academic break. The unprecedented revocation followed a quality assurance process that began with the MB ChB Programme Committee, moving to the Faculty Undergraduate Committee, to the Faculty Board and finally to the University Senate - all of which had student representation. She conceded that the student representatives at the time would not have been Wayne or any of his current committee.

\section{Initial student silence on Basson's teaching questioned}

Moodley questioned why the student body had allowed Basson to continue tutoring for so long without speaking up. 'Perhaps it is because student protests around the country have empowered and liberated students to freely express their views', she speculated, expressing concern that 'a subset of students had no discomfort with his apartheid-related

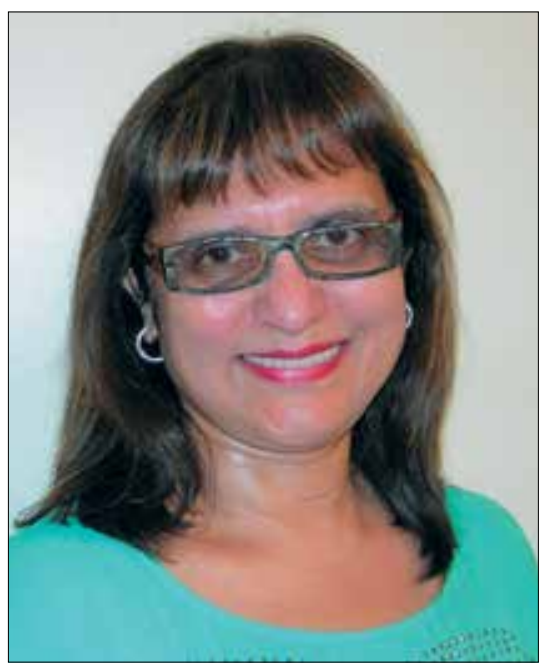

Ex-SAMA President Prof. Ames Dhai. activities that transgressed the foundational principles of the profession and basic respect for human rights'. Yet other students 'showed a profound dialectical capability in sharing the same space with someone they respected as a clinician, yet deplored as a health professional and human being. De Villiers said that there was a well-publicised and regularly used complaints procedure for students, emphasising that there was no complaint on record about Basson's tutelage. Attendance at his tutorials was voluntary, she reaffirmed. Dhai, who is Chairperson of SAMA's Human Rights and Ethics Committee, said: 'It boils down to a question of trust. Clearly, through everything that's happened and what he was convicted of by the HPCSA, there's been a real erosion of integrity on his part. Medical students are in their formative years of study. They learn not only from the formal curriculum but the informal one. Bad habits have been picked up from the hidden curriculum and the behaviour patterns of our teachers. The Remunerative Work outside the Public Service abuse is an excellent example of this. Is he worthy of our trust? In my opinion he's lost people's trust and is not worthy of it, not only because of what he did, but the manner in which he's conducted himself subsequently. His lack of remorse and continuous opposing of Council is absolutely cynical.' Basson said he had 'no idea what the fuss is about. I teach many groups of people and have received no complaints, related to either the giving thereof or the quality thereof, at all over the years, from any of my students. My lectures are a given - the attendees are there of their own volition.' Many doctors and specialists regularly received continuing professional development points by attending his lectures, he added. Moodley challenged the student and lecturer bodies to 'examine the extent to which we idolise and exaggerate the competence of Wouter Basson, perhaps because his worldview of human rights abuses parallels our own worldviews about racism or conversely, what we find reprehensible about him may reflect a poignant sense of injustice induced by the apartheid regime and the institutional culture of some tertiary educational institutions.' She hoped that institutions of higher learning would in future ensure that 'such debate is encouraged contemporaneously and that safe spaces are created for face-to-face discussion, in addition to social media discussions'.

Dr Kgosi Letlape, President of the Health Professions Council of South Africa, said that there were no limitations on Basson's registration with the MDPB. No healthcare practitioner could be restricted in his or her practice until the last legal word had been

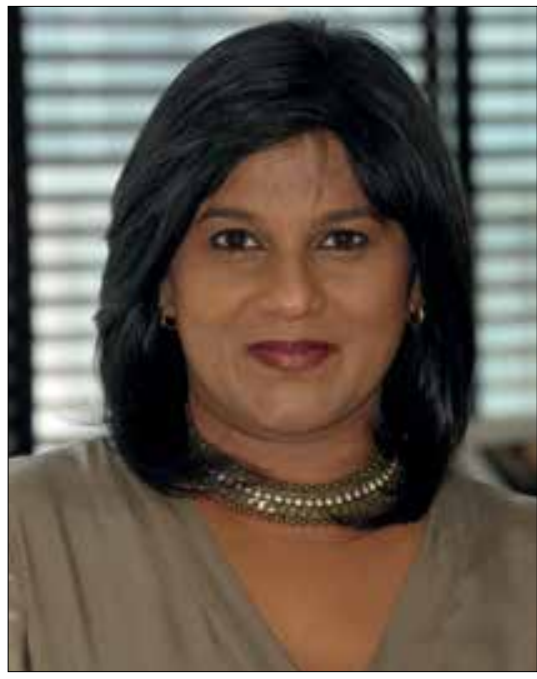

Associate Professor and Head of the Centre for Medical Ethics and Law at Stellenboch University, Prof. Keymanthri Moodley.

spoken. 'He has rights like any other citizen, and the laws of the country still prevail', he stressed.

\section{SAMA Chair: 'don't lean on the private sector'}

SAMA Chairperson Dr Mzukisi Grootboom said he understood what MediClinic was 'trying to drive towards', but disagreed with 'the constant call among the leadership of academic health centres to allow a private practice platform to teach medical students'.

'I don't think it's appropriate. What we need is for these same leaders to advocate for government to do what is correct, and that is to equip and capacitate academic hospitals to cater for and be accessible to the majority of people. The unintended consequence of this [private sector] approach is that it perpetuates the perception that the system has failed. Academic teaching platforms should meet the requirements of teaching medical students. If they allow the situation to deteriorate any further, we won't have a teaching platform.' Focusing on primary healthcare was vital, but not at the expense of tertiary health centres, he added.

Izindaba has learnt that the Tygerberg/ Boland branch of SAMA supported Basson in complaining about the petition against the cardiologist (launched by the People's Health Movement, not SAMA). However, SAMA refused to apologise for supporting the petition, responding that its predecessor (the Medical Association of South Africa, MASA) was a founding member of the World Medical Association, formed in direct response to Nazi atrocities performed by doctors on living human beings. The same 
'covenant', which held that even in times of war no doctor should use their training to kill instead of heal, was abused by MASA when black consciousness leader Steve Biko was murdered in 1977. Basson only recently withdrew his membership of SAMA.

The MDPB found Basson guilty of co-ordinating the large-scale production of illegal psychoactive drugs (including Ecstasy), arming mortars with teargas and providing military operatives with disorientating substances to make illegal cross-border kidnappings easier. $\mathrm{He}$ also made cyanide capsules available to apartheid-era military spies so that they could commit suicide if captured - a slow and painful death, the antithesis of 'quick and painless' James Bond-type spy suicides.
Hugo said in his judgment that medical ethics were 'especially important' in times of war and conflict. Basson had 'defiled the unique and sacred position' of trust in doctors by society that impelled them to stay true to the ethical values of 'beneficence, non-malificence, justice and autonomy'

South African Military Health Service Surgeon General, Lt.-Gen. A P Sedibe, said that Basson was no longer on their payroll, but declined to answer questions on how long he had been. Head of Communications in the national defence ministry, Siphiwe Dlamani, confirmed that the South African National Defence Force (SANDF) was footing Basson's hefty legal bill, 'by virtue of his having been in the SANDF in the past'. The State is paying both the HPCSA's and Basson's legal bills but no state official will reveal or even estimate what this has cost so far. The professional conduct hearing has dragged on six times longer than the corruption trial of the late former police commissioner, Jackie Selebi (2009 - 2012) - and that cost ZAR17 million. Basson was acquitted in a lengthy criminal trial that predated the current ethics-related hearing. When he will be sentenced remained an open question at the time of writing.

\section{Chris Bateman}

chrisb@hmpg.co.za

S Afr Med J 2016;106(1):11-13.

DOI:10.7196/SAMJ.2016.v106i1.10416 